\title{
The color of EPEA: variability in the in situ bio-optical properties in the period 2000-2017
}

\author{
M. Guillermina Ruiz ${ }^{1,2,}{ }^{*}$, Vivian A. Lutz ${ }^{1,2}$, Valeria Segura ${ }^{1}$, Carla F. Berghoff ${ }^{1}$ and Rubén M. Negri ${ }^{1}$ \\ ${ }^{1}$ Instituto Nacional de Investigación y Desarrollo Pesquero (INIDEP), Paseo Victoria Ocampo No 1 , Escollera Norte, B7602HSA - \\ Mar del Plata, Argentina. ${ }^{2}$ Instituto de Investigaciones Marinas y Costeras (IIMyC), Universidad Nacional de Mar del Plata (UNMdP), \\ Consejo Nacional de Investigaciones Científicas y Técnicas (CONICET), Argentina
}

Marine and Fishery Sciences MAFIS

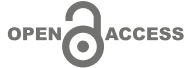

*Correspondence: mgruiz@inidep.edu.ar

Received: 13 July 2020 Accepted: 18 August 2020

ISSN 2683-7595 (print) ISSN 2683-7951 (online)

https://ojs.inidep.edu.ar

Journal of the Instituto Nacional de Investigación y Desarrollo Pesquero (INIDEP)

This work is licensed under a Creative Commons AttributionNonCommercial-ShareAlike 4.0 International License

\begin{abstract}
The 'Estación Permanente de Estudios Ambientales' (EPEA, $38^{\circ} 28^{\prime}$ S-57 $47^{\circ}$ ' W, Argentina) is an ecological time series of in situ observations started in 2000 aiming to assess changes in the marine environment and plankton communities under a global change scenario. Bio-optical properties are studied at EPEA since the color of the ocean undergoes temporal fluctuations, both for natural and anthropogenic causes. Here we assessed whether bio-optical properties at EPEA have changed during 2000-2017, identifying the occurrence of special events and inter-annual trends in these properties. An increasing trend in chlorophyll-a concentration, possibly due to an increase in the smaller fraction of phytoplankton was observed. Although the absorption coefficient of phytoplankton did not follow a significant trend, it represented the occurrence of special events of high biomass suggesting that satellite information should be useful for the study site. The specific absorption coefficient of phytoplankton and the blue to red absorption ratio showed high values in summer and low in winter, according to the probable dominance of different size cells and their expected acclimation to the light regime. These results emphasize the relevance of periodic bio-optical in situ observations in understanding coastal ecosystems in a context of climate change.
\end{abstract}

Key words: Chlorophyll-a, bio-optical properties, inter-annual variability, EPEA, South Atlantic.

El color de la EPEA: variabilidad en las propiedades bio-ópticas in situ en el período 2000-2017

RESUMEN. La "Estación Permanente de Estudios Ambientales" (EPEA, 38 28' S-57 41' W, Argentina) es una serie de tiempo ecológica de observaciones in situ iniciada en 2000 con el objetivo de evaluar los cambios en el medio marino y las comunidades de plancton en un escenario de cambio global. Las propiedades bio-ópticas se estudian en la EPEA ya que el color del océano sufre fluctuaciones temporales, tanto por causas naturales como antropogénicas. Aquí evaluamos si las propiedades bio-ópticas de la EPEA han cambiado durante 2000-2017, identificando la ocurrencia de eventos especiales y tendencias interanuales en estas propiedades. Se observó una tendencia creciente en la concentración de clorofila-a, posiblemente debido a un aumento en la fracción más pequeña de fitoplancton. Aunque el coeficiente de absorción del fitoplancton no siguió una tendencia significativa, representó la ocurrencia de eventos especiales de alta biomasa, lo cual sugiere que la información satelital debería ser útil para el sitio de estudio. El coeficiente de absorción específico del fitoplancton y la relación de absorción de azul a rojo mostraron valores altos en verano y bajos en invierno, de acuerdo con el probable dominio de las células de diferentes tamaños y su aclimatación esperada al régimen de luz. Estos resultados enfatizan la relevancia de las observaciones bio-ópticas periódicas in situ para comprender los ecosistemas costeros en un contexto de cambio climático.

Palabras clave: Clorofila-a, propiedades bio-ópticas, variabilidad interanual, EPEA, Atlántico Sur. 


\section{INTRODUCTION}

The importance of evaluating the role of the oceans in a global climate change scenario is recognized worldwide. Ecological time series provide observations that allow assessing changes occurring in the marine environment and its biota in the long run (Ducklow et al. 2009). The 'Estación Permanente de Estudios Ambientales' (EPEA, $38^{\circ} 28^{\prime} \mathrm{S}-57^{\circ} 41^{\prime} \mathrm{W}$, Argentina) was initiated in 2000 with the aim of understanding the functioning of planktonic communities and try to distinguish the possible effects of climate change. Besides several physical, chemical, oceanographic and biological variables, bio-optical properties are also studied at EPEA since the color of the waters is one of the ocean characteristics that undergoes temporal fluctuations, both as part of natural cycles and due to the impact of anthropogenic global change. Hence, the study of the bio-optical properties has become an invaluable tool to monitor changes in marine ecosystems.

Bio-optical properties are crucial in marine ecological studies because light is an essential factor governing the heat content in the ocean and affecting its physical conditions. Light available in the water triggers biological processes, providing the energy required in the photosynthesis and hence determining in great part the amount of primary production fueling the marine food web, regulating ontogeny in different organisms (i.e., larval stages), trophic migrations (e.g., diel vertical movements), and facilitating or avoiding predation (by affecting the visual field). Furthermore, given the anthropogenic impact on the climate, with near $28 \%$ of the anthropogenic carbon dioxide released to the atmosphere captured by the ocean (IPCC 2019), there is a need to understand changes in phytoplankton bio-optical properties since on a global scale phytoplankton contributes with about half of the earth primary production (Longhurst
1995). Dutkiewicz et al. (2019), using a complex biogeochemical model estimated that by the year 2100 changes in phytoplankton community composition would cause a $63 \%$ change on the reflectance in the blue region of the electromagnetic spectrum (an essential bio-optical property of the oceans). Therefore, long-term records of bio-optical properties in different places of the ocean would provide ground-truth data to analyze in detail these possible changes.

Once the incident solar radiation passes through the ocean surface it is attenuated due to the scattering and absorption processes as a consequence of its interaction with the seawater (SW) and the active optical components (OACs) present in it. OACs are the phytoplankton (Phy), the non-algal particles (NAP) and the chromophoric dissolved organic matter (CDOM). Hence, the amount of light available for the photosynthesis depends on the types and proportions in which the different OACs are present in a certain time and place. The degree of light attenuation can be measured by the inherent bio-optical properties, mainly the absorption and the dispersion coefficient $(a(\lambda)$ and $b(\lambda)$ respectively, $\mathrm{m}^{-1}$ ), which are quantities that have spectral dependence and are governed by a strict additivity (Prieur and Sathyendaranath 1981). This means that the total $a(\lambda)$ is equivalent to the sum of the $a_{S W}(\lambda), a_{P h y}(\lambda), a_{N A P}(\lambda)$ and $a_{C D O M}(\lambda)$. In turn, theoretically, the $a(\lambda)$ of each OAC can be expressed as the product between a specific coefficient and its concentration, that is, a vector that represents the spectral signature of the component and a scalar associated with the amount of that component present.

The spectral absorption characteristics of phytoplankton depend on the species, their size and specific ensemble of pigments, as well as to their physiological status (Sathyendranath et al. 1987; Johnsen and Sakshaug 1996; Lutz et al. 2001; Lutz et al. 2003). It has been observed that larger cells have a relatively flatter absorption spectrum, measurable by a lower value of the specific 
absorption coefficient of phytoplankton at 443 $\mathrm{nm}$ (absorption per concentration unit of chlorophyll-a, $a^{B}{ }_{\text {Phy }}(443)$ ), and a lower ratio of absorption between the blue and red bands $\left[a_{P h y}(443) / a_{P h y}(676)\right]$, than smaller cells. At the same time, any given species can photoacclimate to the intensity of light to which it is exposed by adjusting the proportion of its different pigments, increasing those with a light-harvesting (photoprotective) function at low (high) irradiances, which results in spectral changes of the absorption spectrum (i.e., a lower value of $a_{P h y}^{B}(443)$, and $\left[a_{P h y}(443) / a_{P h y}(676)\right]$ at low irradiances, and vice versa). These effects, which respond to the principle of 'packaging effect' (Duyens 1956; Sathyendranath et al. 1987; Bricaud et al. 1995), have been reported for different places of the world ocean (Ciotti et al. 2002; Babin et al. 2003; Lutz et al. 2003) and the Argentine Sea (Ferreira et al. 2009; Segura et al. 2013; Williams et al. 2018; Delgado et al. 2019).

Coastal waters as the case of EPEA have a complex mixture of OACs, which vary their concentrations with time. The inherent optical properties $\left(a_{P h y}(\lambda), a_{N A P}(\lambda), a_{C D O M}(\lambda)\right)$, the concentration of chlorophyll-a as a proxy of phytoplankton biomass (both, the total fraction, $\mathrm{Chl}_{T}$, and that contributed by the phytoplankton fraction less than $5 \mu \mathrm{m}$ in diameter, $C h l_{<5}$ ) and the irradiance integrated in the range of 'photosynthetically available radiation' (PAR, 400-700 nm) incident on the surface, $E_{0}(P A R)$ and the downwelling on the water column, $E_{d}(P A R)$, have been systematically determined as part of the measurements performed at EPEA. A first analysis of bio-optical characteristics for the 2000-2001 annual cycle at EPEA (Lutz et al. 2006) evidenced that CDOM was the main contributor to absorption, and that lower values of $a^{B}{ }_{P h y}(443)$ were found in winter (especially during a bloom of a large diatom) and higher in summer when small cells (especially of the Genus Synechococcus) predominated. This last result was confirmed in a study of ultra-phytoplankton in the summer 2001-2002 (Silva et al. 2009). More recently, an analysis of validation of satellite chlorophyll-a for 18 years of the time series (Ruiz 2018) reported that CDOM was the main $\mathrm{OAC}$ throughout the year, and hence affecting the remote sensing signal of ocean-color at EPEA, overestimating $C h l_{T}$ mainly in summer.

To assess whether bio-optical properties at EPEA have experienced a change during the 20002017 period, the main objectives of this work were: a) to provide a general description of variations in these properties; b) to identify the occurrence of special events; c) to analyze the occurrence of inter-annual trends in these properties.

\section{MATERIALS AND METHODS}

\section{Study area}

EPEA is located north of the Argentine continental shelf $\left(38^{\circ} 28^{\prime} \mathrm{S}-57^{\circ} 41^{\prime} \mathrm{W}\right), 13.5$ nautical miles from the coast and close to the $50 \mathrm{~m}$ isobaths (Figure 1). Its hydrographical regime has been described as the transition between coastal waters of high salinity and waters of the middle shelf (Auad and Martos 2012). Occasionally the site can receive less salty waters from the North, leading salinity to be less than 31.0 , particularly in summer when the Río de la Plata reaches its maximum southern extension (Carreto et al. 1995). A marked seasonal cycle typical of temperate regimes has been observed at the EPEA. Sea surface temperature varies between $10^{\circ} \mathrm{C}$ and $21^{\circ} \mathrm{C}$ and salinity values vary from 33.5 to 34.1 (Carreto et al. 2004; Lutz et al. 2006; Silva 2009; Ruiz 2018). The phytoplankton community reaches its maximum biomass during winter, dominated mainly by micro planktonic diatoms $(20-200 \mu \mathrm{m})$ (Negri and Silva 2011), while in summer the ultraphytoplankton fraction (less than $5 \mu \mathrm{m}$ in diameter) makes the major contribution to total phytoplankton biomass (Silva et al. 2009). 


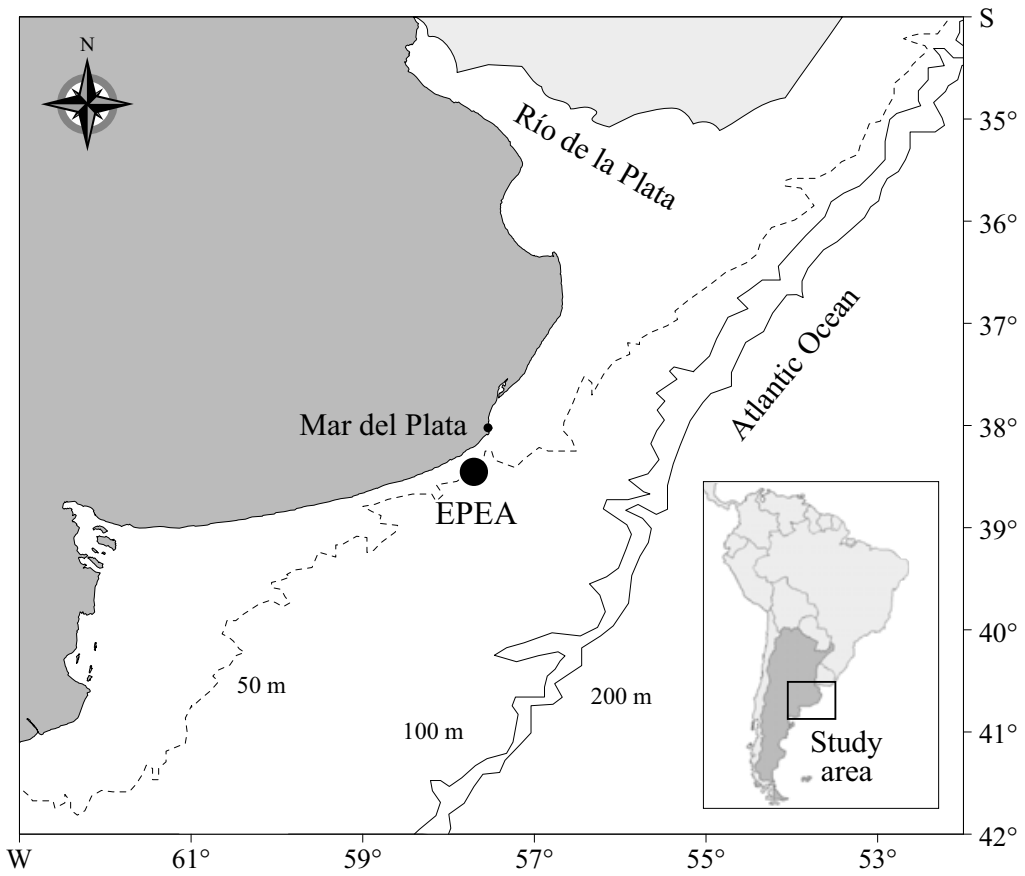

Figure 1. 'Estación Permanente de Estudios Ambientales' (EPEA), $38^{\circ} 28^{\prime}$ S-57 41' W.

\section{Sampling and determinations at EPEA station}

The study period considered in this work was January 2000-December 2017 with a monthly sampling frequency (with gaps), covering 119 visits to EPEA, performed in different scientific research vessels from the Instituto Nacional de Investigación y Desarrollo Pesquero (INIDEP), the Navy and the Naval Prefecture of Argentina. Not all variables were obtained in all cruises. For this work we used data from samples collected at $5 \mathrm{~m}$ depth.

\section{Chlorophyll-a total concentration $\left(\mathrm{Chl}_{T}\right)$}

Water samples were collected at $5 \mathrm{~m}$ depth using a Niskin bottle. A total of 119 water samples for $C h l_{T}$ determination were collected in dark bottles and immediately filtered after collection on glass microfiber filters, Grade GF/F $0.7 \mu \mathrm{m}$, under dim light and low pressure $(<35 \mathrm{kPa})$. Filters were kept in liquid nitrogen $\left(-195.8{ }^{\circ} \mathrm{C}\right)$ and in an ultrafreezer $\left(-86^{\circ} \mathrm{C}\right)$ until analysis. For the determination $C h l_{<5}$, water samples were pre-filtered through a $5 \mu \mathrm{m}$ pore Nuclepore membrane filters and then the same procedure as for the $C h l_{T}$ was applied to the filtrate. In the laboratory, $C h l_{T}$ and $C h l_{<5}$ were determined using a spectrofluorometer (Perkin Elmer LS3) following the HolmHansen et al. (1965) method for samples collected between 2000-2005 and a modified version according to Lutz et al. (2010) since 2006.

\section{Particulate absorption}

Samples for determination of absorption spectra of total particulate material were collected, filtered and preserved following the same procedure described for $C h l_{T}$. A total of 110 samples were analyzed during 2000-2017 using a spectrophotometer (Shimadzu UV-210-A), placing filters close to the photomultiplier for samples collected until 2006, and on a spectrophotometer (Shimadzu UV-2450) with an integrating sphere from 2006 onwards, following the quantitative filter technique (Mitchell 1990), and using the amplifi- 
cation factors of Hoepffner and Sathyendranath (1992). Then, the method of Kishino et al. (1985) was used to determine the $a_{N A P}(\lambda)$ spectrum and $a_{P h y}(\lambda)$ was estimated by subtracting $a_{N A P}(\lambda)$ from $a_{p}(\lambda)$. More details can be found elsewhere (Lutz et al. 2006; Ruiz 2018). The specific absorption coefficient of phytoplankton in the blue, which is $a_{P h y}(443)$ normalized by $C h l_{T}$ $\left(a_{P h y}^{B}(443), \mathrm{m}^{2} \mathrm{mg}^{-1}\right)$, and the ratio of the absorption in the blue to the red $\left(\left[a_{P h y}(443) / a_{P h y}(676)\right]\right)$ were derived from $a_{P h y}(\lambda)$ spectra.

\section{Chromophoric dissolved organic matter (CDOM)}

For the determination of CDOM absorption spectra, a total of 78 seawater samples were collected directly from the Niskin bottle into acidwashed transparent borosilicate bottles with teflon lids, and kept in the dark at $4{ }^{\circ} \mathrm{C}$ until scanned at the laboratory (usually within 1 to 3 days after each cruise). Samples were filtered through pre-combusted glass microfiber filters Grade GF/F $0.7 \mu \mathrm{m}$ at $450{ }^{\circ} \mathrm{C}$ during $3.5 \mathrm{~h}$, and the $a_{C D O M}(\lambda)$ of the filtrate determined in a UVVIS spectrophotometer (Shimadzu UV-210-A) for samples collected until 2006 using $4 \mathrm{~cm}$ optical path quartz cuvettes (Lutz et al. 2006), and in a UV-VIS spectrophotometer using $10 \mathrm{~cm}$ optical path quartz cuvettes since 2006 until present (Mitchell 1990; Ruiz et al. 2017).

\section{Vertical profiles of conductivity-temperature- depth (CTD)}

CTD profiles in the water column were recorded at each cruise using a Seabird SBE19 or SBE 911 CTD, according to availability of the equipment. Quality controlled temperature data (processed by the Physical Oceanography Cabinet of INIDEP) was used to estimate the depth of the thermocline $\left(Z_{d T d Z}, \mathrm{~m}\right)$, defined as the depth at which the maximum value of the first derivative of the temperature respect to depth, $d T d Z$, was found. Note that this parameter is indicative of the stratification-mixing state of the water column. The depth $Z=42 \mathrm{~m}$ was used as a fixed limit, when the water column was completely mixed, in order to avoid variability regarding the deepest depth reached by the CTD.

\section{In situ photosynthetically available radiation (PAR)}

A submersible radiometer (PUV-500/510B, Biospherical Instrument) was deployed manually by releasing a conductor cable to record the downwelling irradiance integrated between 400$700 \mathrm{~nm}\left(E_{d}(P A R), \mu \mathrm{mol}\right.$ quanta $\left.\mathrm{m}^{-2} \mathrm{~s}^{-1}\right)$ as a function of depth. The euphotic depth $\left(Z_{e u}, \mathrm{~m}\right)$ was determined as the depth at which the closest value to the $1 \%$ of the recorded $E_{0}(P A R)$ occurred. When the water column was completely illuminated and the $1 \%$ of $E_{0}(P A R)$ was not reached, $Z_{\text {eu }}$ was assumed to be $40 \mathrm{~m}$.

\section{Satellite photosynthetically available radiation (PAR)}

Monthly averages of incident solar radiation were estimated using the standard photo-synthetically available radiation (PAR) satellite product. PAR product was retrieved from monthly composite images collected by the Aqua Moderate Resolution Imaging Spectroradiometer (MODIS) at spatial resolution of $4 \mathrm{~km}$, at Level 3 Standard Mapped Image (Version R2014.0, Ocean Color Website http://oceancolor.gsfc.nasa.gov). PAR data was provided by the Remote Sensing Cabinet of INIDEP.

\section{Statistical analysis}

Descriptive statistics was performed on the bio-optical properties and thermal stratification parameters. Spearman correlations were used to explore the relationship between the different variables under study. Then, monthly averages were plotted against the months to evidence seasonal cycles. Values deviating $>2$ standard deviations (SD) from the mean were considered 'extreme values' or extreme events (Davies and Gather 1993). Long term variability was assessed 
by the Seasonal Mann Kendall Trend Test (SMK test, Hirsch and Slack 1984), a non-parametric test for seasonal data. For that, a FORTRAN routine implemented by Hernández and Mendiolar (2018) was used. Values higher than mean > 2 SD were excluded of the trend calculation for each variable.

\section{RESULTS}

\section{Bio-optical properties and thermal stratifica- tion parameters}

The thermal classification criterion proposed by Baldoni (2010) was applied to identify seasonal differences in each bio-optical property. It can be observed that all properties showed a broad range in their values, mainly attributed to seasonal variations, but also to the occurrence of special events (Table 1). Phytoplankton absorption coefficient presented a high standard deviation relative to the mean value. On average, the contribution of the small fraction of phytoplankton (quantified as $\% C h l_{<5}$ ) to the total concentration of chlorophyll was not negligible.

\section{Annual cycle of bio-optical properties and thermal stratification parameters}

Incident PAR (estimated by the satellite product) at EPEA reaches a maximum average value in December and a minimum in June (Figure 2), denoting a sinusoidal cycle expected for a middle latitude site in the Southern hemisphere. Variability during winter months was notoriously smaller than during the rest of the year. Correspondingly, light penetration is maximum in the warm period $\left(Z_{e u}=31.70 \pm 8.02\right)$, reaching depths close to the bottom of the water column in January, and is minimum in the cold period $\left(Z_{\text {eu }}=24.78 \pm 5.01\right.$; Figure 2). Since light penetration is attenuated by OACs present in the water column, $Z_{e u}$ shows an opposite sinusoidal pattern distorted respect to the observed in incident PAR cycle. On the other hand, the water column is homogeneous in winter, and a thermocline starts to develop in spring reaching its shallowest depths in summer (average for December $Z_{d T d Z}=27 \pm 8 \mathrm{~m}$; Figure 3). Variability of $Z_{d T d Z}$ is notoriously higher during the cold to warm and warm periods than during the warm to cold and cold periods.

EPEA is characterized by optically complex waters during the whole annual cycle, with $\mathrm{CDOM}$ as the main OAC contributing to total absorption (Figure 4). Phytoplankton biomass at EPEA, here estimated by $C h l_{T}$, had an annual mean of $1.162 \pm 1.019 \mathrm{mg} \mathrm{m}^{-3}$, with higher values during the cold period $\left(C h l_{T}=1.49 \pm 1.14\right)$, and lower during the warm period $\left(C h l_{T}=0.89 \pm\right.$ 0.89 ), although dispersion is high (Figure 5). $\mathrm{Chl}_{<5}$ contributed on average $45 \%$ to $C h l_{T}$ and mean monthly values were relatively similar throughout the annual cycle (Table 1; Figure 6). Specific absorption coefficient of phytoplankton $\left(a^{B}{ }_{P h y}(443)\right)$ and the ratio of absorption in the blue over the red $\left[a_{P h y}(443) / a_{P h y}(676)\right]$ carry information regarding the packaging effect. Although both parameters followed the same patterns, the latter showed a clearest feature of increase towards summer (Figure 7), when small cells are predominant and they are photo-acclimated to high incident light (Silva et al. 2009).

\section{Relationships between bio-optical and physi- cal properties}

Spearman rank correlations (rho) were computed in order to explore the relationship between bio-optical and physical properties at EPEA (Table 2). Temperature was positively correlated with $Z_{e u}$ and negatively correlated with $Z_{d T d Z}$. These relationships showed that as the spring progresses, the increasing incident irradiance and hence the increase in air temperature, induced the warming of the upper sea layer and, consequently, the thermal stratification (also denoted by the 


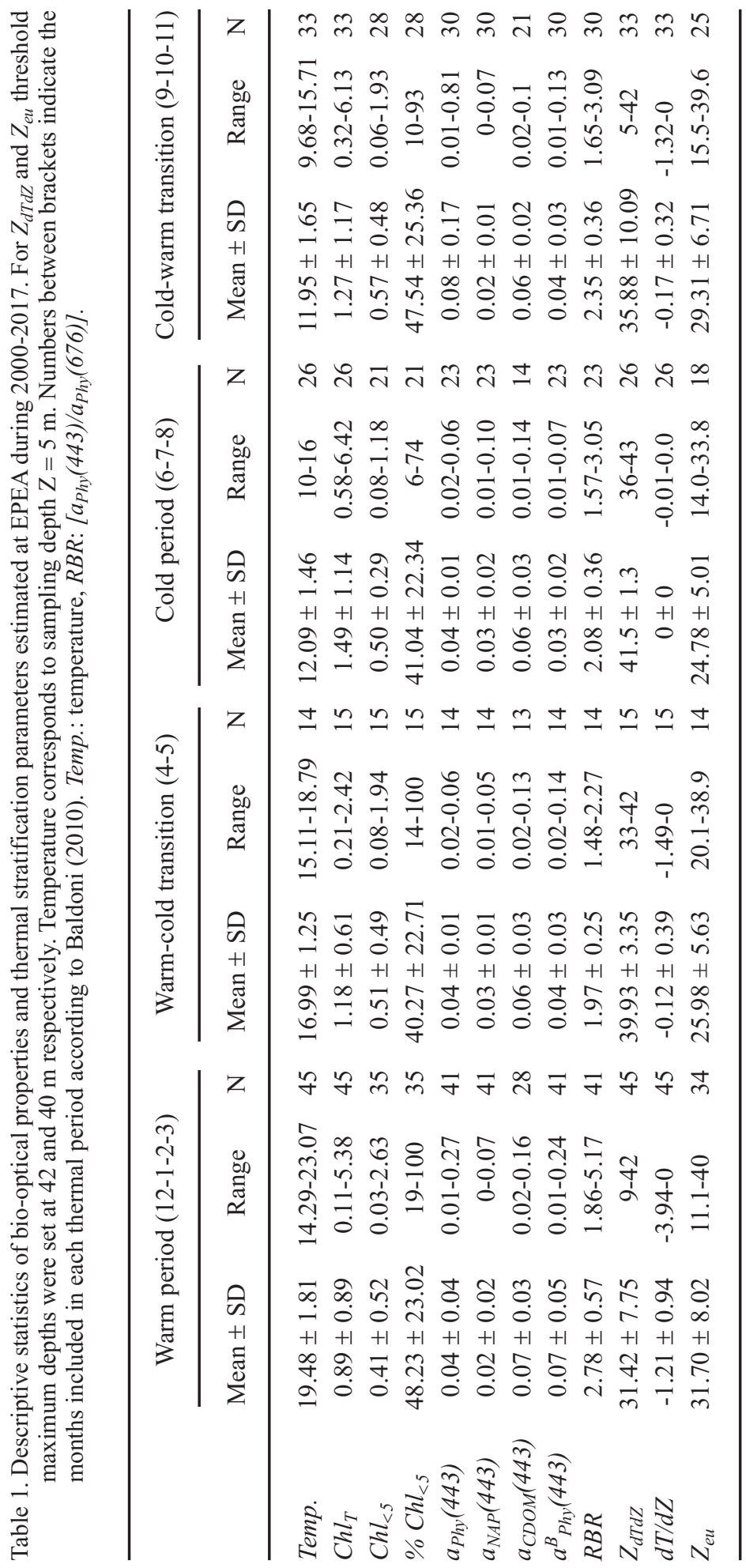




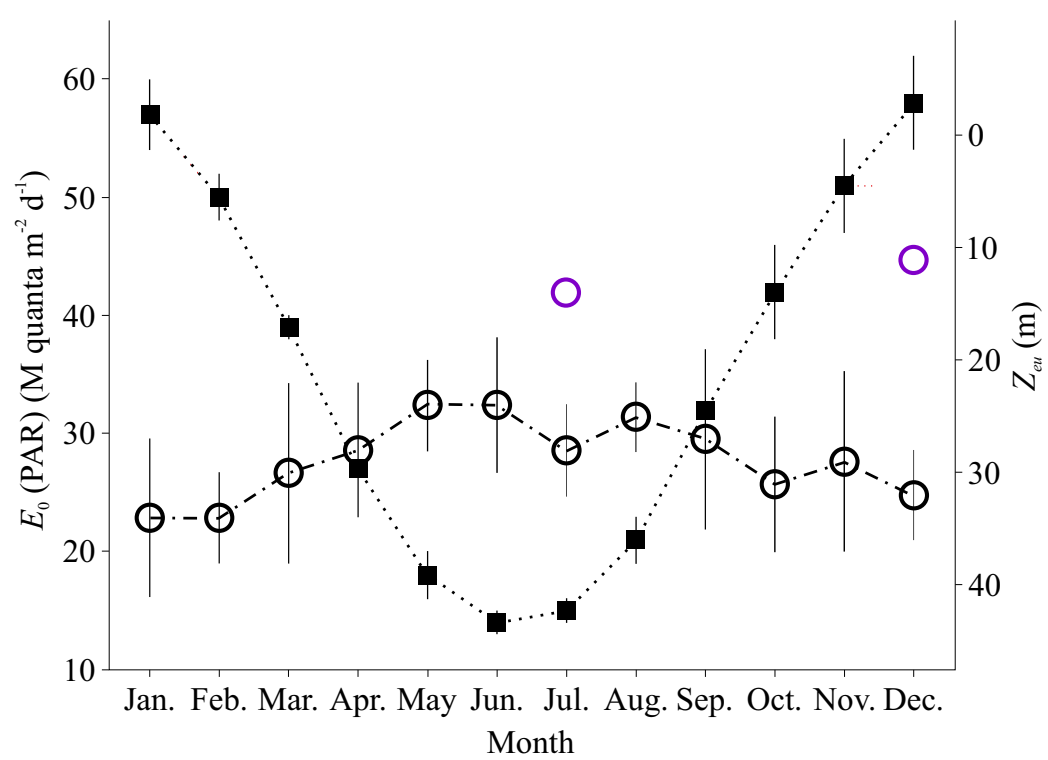

Figure 2. Monthly satellite incident PAR irradiance (black squares) and monthly averages $Z_{e u}$ (open circles) at EPEA for 20032017. Purple circles indicate extreme $Z_{e u}$ values (>2 SD), not used in the calculation of the means. Bars indicate SD.

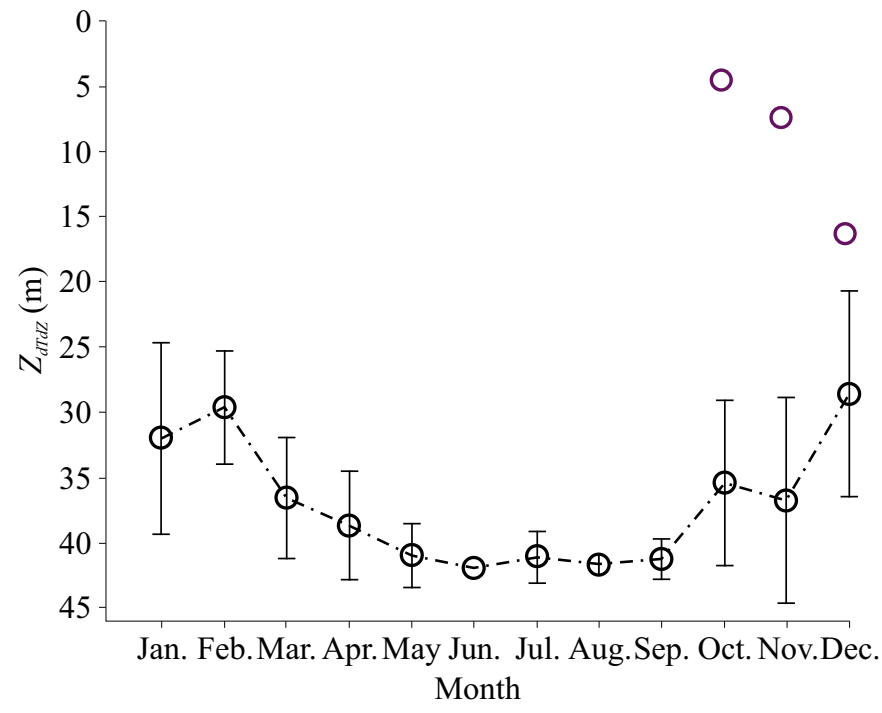

Figure 3. $Z_{d T d Z}$ for 2000-2017. Black circles represent monthly averages. Bars indicate SD. Purple circles indicate extreme values $(>2 \mathrm{SD})$, not used in the calculation of the means.

positive correlation between $Z_{e u}$ and $d T d Z$ ). In turn, $Z_{e u}$ showed a significant negative correlation with $Z_{d T d Z}$, that is, the more mixed the water column, the weaker the stratification and the shallower the light penetration.
$C h l_{T}$ had a significant negative correlation with temperature, $d T d Z, Z_{e u}, a^{B}{ }_{P h y}(443)$ and $\left[a_{P h y}(443) /\right.$ $\left.a_{P h y}(676)\right]$, while it was positively correlated with $Z_{d T d Z}$. These relationships indicated that phytoplankton biomass tended to be higher during win- 


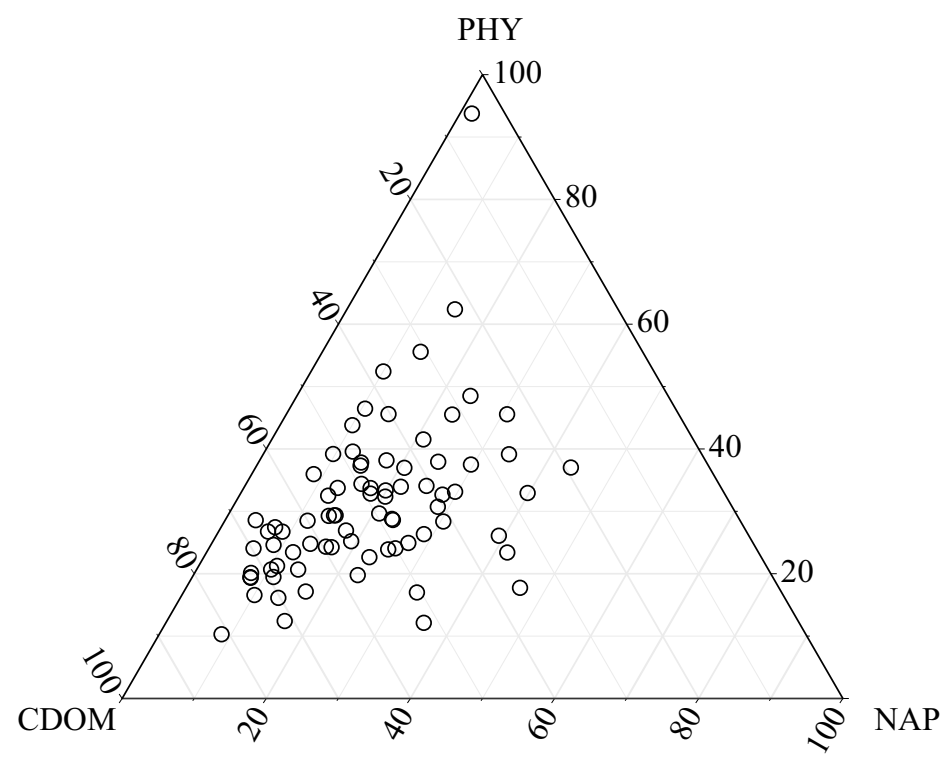

Figure 4. Contribution to total absorption coefficient at $443 \mathrm{~nm}$ of optically active components (phytoplankton, NAP and $\mathrm{CDOM}$ ) expressed as percentage in a ternary plot.

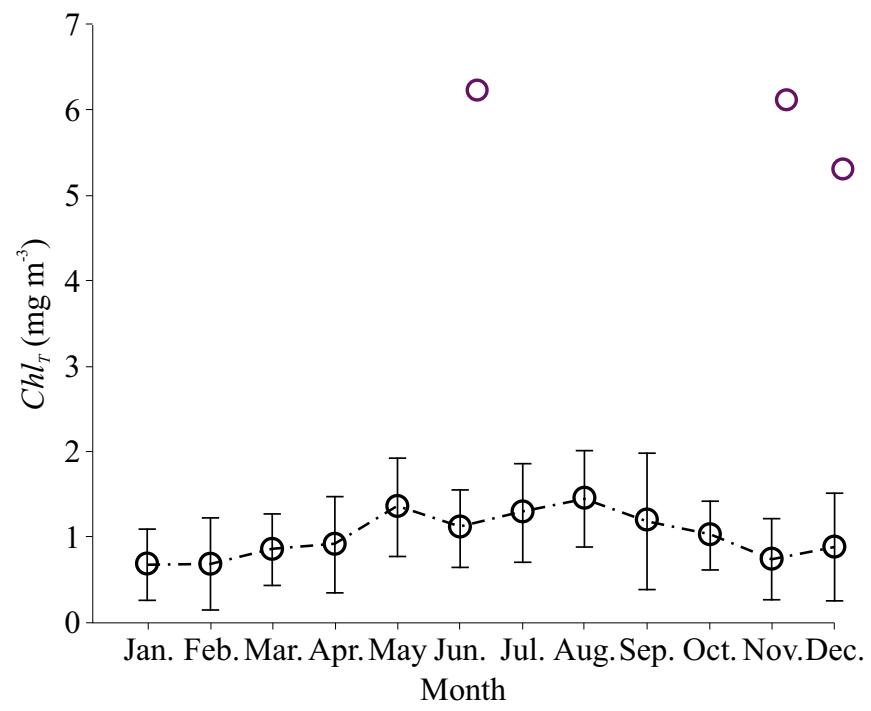

Figure 5. In situ $\mathrm{Chl}_{T}$ for 2000-2017. Black circles represent monthly averages. Bars indicate SD. Purple circles indicate extreme values $(>2 \mathrm{SD})$, excluded from the calculation of the means.

ter, mainly due to the presence of larger cells with lower light absorption efficiency and greater packaging effect coupled with a mixed water column and less light penetration. This interpretation is consistent with the negative correlations found between $a^{B}{ }_{P h y}(443)$ and $\left[a_{P h y}(443) / a_{P h y}(676)\right]$ with $Z_{d T d Z}$, and positive correlation with $d T d Z$ and $Z_{e u}$. Regarding the relationships with the OACs, $\mathrm{Chl}_{T}$ was more positively correlated with $a_{P h y}(443)$ than with $a_{N A P}(443)$ and non-correlated 


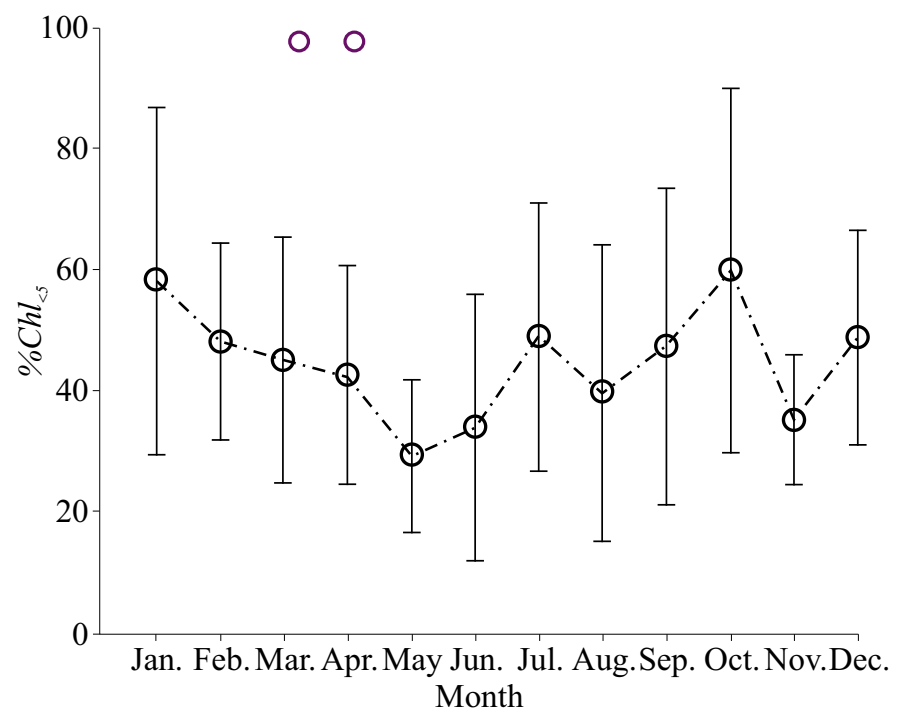

Figure 6. Percentage of $C h l_{<5}$ over $C h l_{T}$ for 2000-2017. Black circles represent monthly averages. Bars indicate SD. Purple circles indicate extreme values $(>2 \mathrm{SD})$, excluded from the calculation of the means.

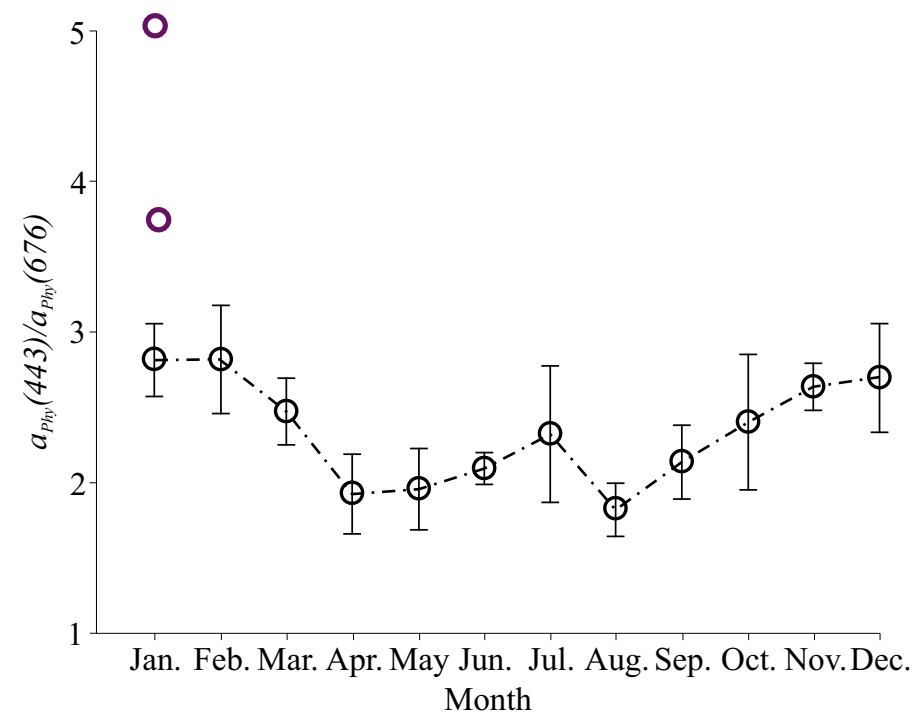

Figure 7. Values of $\left[a_{P h y}(443) / a_{P h y}(676)\right]$ for 2000-2017. Black circles represent monthly averages. Bars indicate SD. Purple circles indicate extreme values $(>2 \mathrm{SD})$, excluded from the calculation of the means.

with $a_{C D O M}(443)$, which was expected in part since $a_{N A P}(443)$ increased with mixing also due to resuspension of bottom material. In turn, $a_{C D O M}(443)$ was not correlated with stratification parameters, suggesting an independent behavior of the mixing-stratification cycle at EPEA station.
$\% C h l_{<5}$ showed only a weak positive significant correlation with $Z_{e u}$, $d T d Z$ and $\left[a_{P h y}(443)\right.$ $\left./ a_{P h y}(676)\right]$, suggesting that when light penetration is deeper and stratification stronger at EPEA, the percentage of smaller cells tended to increase. 
Table 2. Spearman correlation coefficients between bio-optical and physical properties at EPEA. Spearman coefficient of correlation (rho), probability (p) and data number (n) used are written from top to bottom. Temp.: temperature, $R B R$ : $\left[a_{P h y}(443) / a_{P h y}(676)\right]$. Bold values are significant at a $\alpha=0.05$ confidence level.

\begin{tabular}{|c|c|c|c|c|c|c|c|c|c|c|}
\hline & $\mathrm{Chl}_{T}$ & $a_{N A P}(443)$ & $a_{P h y}(443)$ & $a_{\text {Phy }}^{B}$ (443) & $R B R$ & $a_{C D O M}(443)$ & $Z_{d T d Z}$ & $d T d Z$ & $Z_{\text {eu }}$ & $\% C h l_{<5}$ \\
\hline \multirow[t]{3}{*}{ Temp. } & -0.307 & -0.117 & 0.016 & 0.391 & 0.500 & 0.031 & -0.505 & 0.588 & 0.311 & 0.104 \\
\hline & 0.000 & 0.224 & 0.869 & 0.000 & 0.000 & 0.785 & 0.000 & 0.000 & 0.003 & 0.295 \\
\hline & 118 & 109 & 109 & 109 & 109 & 77 & 118 & 118 & 91 & 102 \\
\hline \multirow[t]{3}{*}{$C h l_{T}$} & & 0.238 & 0.584 & -0.639 & -0.365 & 0.229 & 0.340 & -0.454 & -0.647 & -0.061 \\
\hline & & 0.012 & 0.000 & 0.000 & 0.000 & 0.044 & 0.000 & 0.000 & 0.000 & 0.542 \\
\hline & & 110 & 110 & 110 & 110 & 78 & 119 & 119 & 92 & 103 \\
\hline \multirow[t]{3}{*}{$a_{N A P}(443)$} & & & 0.336 & 0.007 & -0.233 & 0.137 & 0.193 & -0.361 & -0.638 & -0.404 \\
\hline & & & 0.000 & 0.945 & 0.014 & 0.232 & 0.043 & 0.000 & 0.000 & 0.000 \\
\hline & & & 110 & 110 & 110 & 78 & 110 & 110 & 90 & 99 \\
\hline \multirow[t]{3}{*}{$a_{P h y}(443)$} & & & & 0.136 & -0.093 & 0.230 & 0.150 & -0.178 & -0.607 & -0.031 \\
\hline & & & & 0.157 & 0.335 & 0.043 & 0.117 & 0.062 & 0.000 & 0.762 \\
\hline & & & & 110 & 110 & 78 & 110 & 110 & 90 & 99 \\
\hline \multirow{3}{*}{$a_{P h y}^{B}(443)$} & & & & & 0.449 & -0.075 & -0.386 & 0.475 & 0.268 & -0.061 \\
\hline & & & & & 0.000 & 0.513 & 0.000 & 0.000 & 0.011 & 0.551 \\
\hline & & & & & 110 & 78 & 110 & 110 & 90 & 99 \\
\hline \multirow[t]{3}{*}{$R B R$} & & & & & & 0.022 & -0.610 & 0.661 & 0.468 & 0.206 \\
\hline & & & & & & 0.848 & 0.000 & 0.000 & 0.000 & 0.040 \\
\hline & & & & & & 78 & 110 & 110 & 90 & 99 \\
\hline \multirow[t]{3}{*}{$a_{C D O M}(443)$} & & & & & & -0.045 & 0.004 & -0.209 & 0.002 & \\
\hline & & & & & & & 0.693 & 0.972 & 0.072 & 0.987 \\
\hline & & & & & & & 78 & 78 & 75 & 77 \\
\hline \multirow[t]{3}{*}{$Z_{d T d Z}$} & & & & & & & & -0.704 & -0.392 & -0.095 \\
\hline & & & & & & & & 0.000 & 0.000 & 0.341 \\
\hline & & & & & & & & 119 & 92 & 103 \\
\hline \multirow[t]{3}{*}{$d T d Z$} & & & & & & & & & 0.536 & 0.200 \\
\hline & & & & & & & & & 0.000 & 0.043 \\
\hline & & & & & & & & & 92 & 103 \\
\hline \multirow[t]{3}{*}{$Z_{e u}$} & & & & & & & & & & 0.316 \\
\hline & & & & & & & & & & 0.002 \\
\hline & & & & & & & & & & 91 \\
\hline
\end{tabular}

Inter-annual variations in bio-optical properties and extreme events

Time series of bio-optical observations throughout the study period (2000-2017) reflected the repetition of seasonal cycles as well as the occurrence of extreme events (Figures 8, 9 and 10) which were associated to specific events involving an exceptional increase in phytoplankton abundance. An extremely high $C h l_{T}$ value of $6.420 \mathrm{mg} \mathrm{m}^{-3}$ (the highest for the entire time series) was recorded in June 2001, but unfortu- 


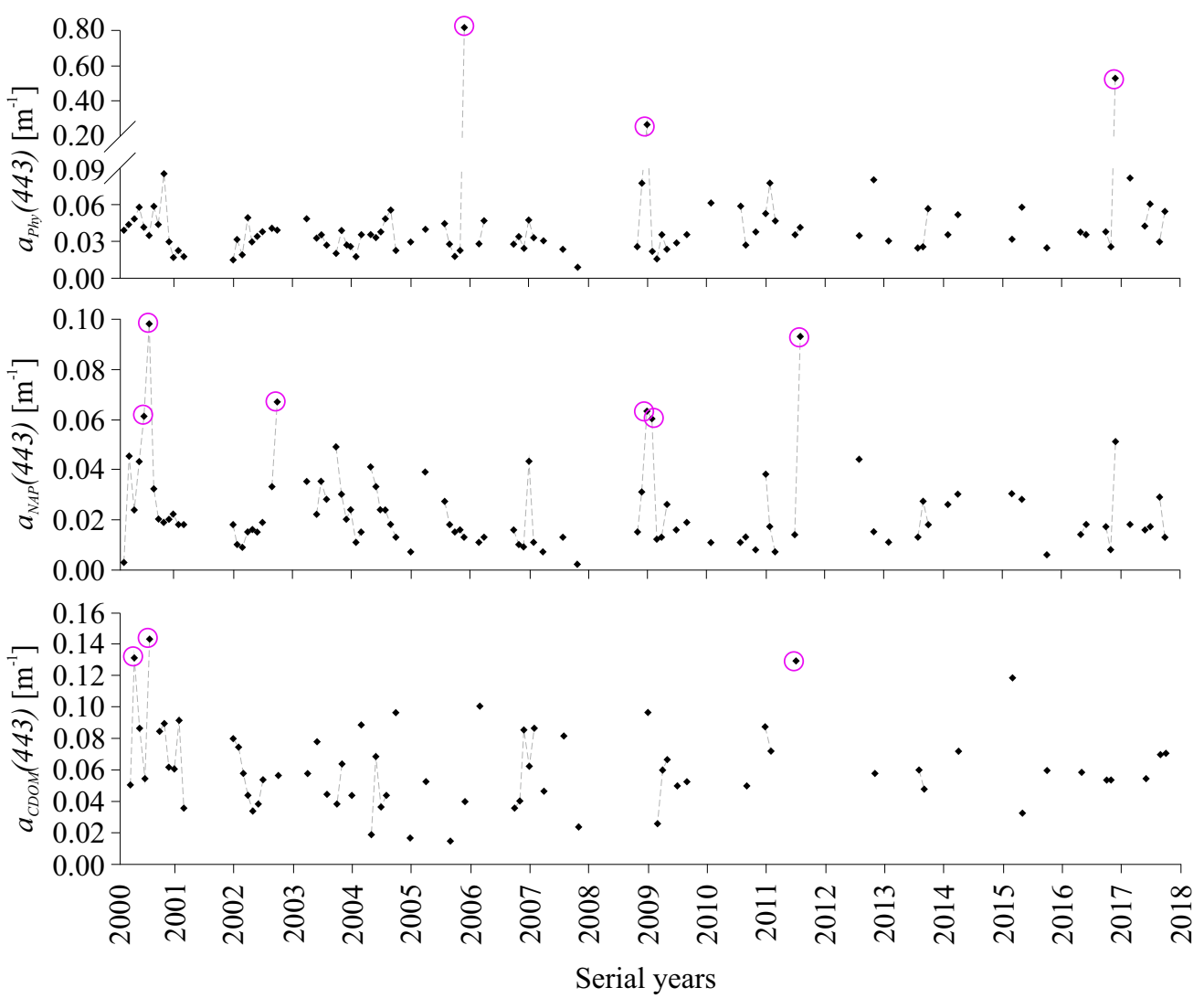

Figure 8. Inter-annual distribution of coefficients of light absorption at $443 \mathrm{~nm}$ by phytoplankton $\left[a_{P h y}(443)\right]$, non-algal particles $\left[a_{N A P}(443)\right]$, and CDOM $\left[a_{C D O M}(443)\right]$ estimated for $5 \mathrm{~m}$ samples at EPEA for the period 2000-2017. Purple circles indicate extreme values ( $>2$ standard deviations).

nately no bio-optical data is available for that sampling. In November 2005 an event characterized by values of $C h l_{T}=6.130 \mathrm{mg} \mathrm{m}^{-3}, a_{P h y}(443)$ $=0.811 \mathrm{~m}^{-1}$ and $a_{N A P}(443)=0.0128 \mathrm{~m}^{-1}$ was observed. In December 2008 another maximum of phytoplankton occurred, characterized by high values of chlorophyll concentration and OACs absorption $\left(C h l_{T}=5.377 \mathrm{mg} \mathrm{m}^{-3}, a_{P h y}(443)=\right.$ $0.266 \mathrm{~m}^{-1}$ and $\left.a_{N A P}(443)=0.063 \mathrm{~m}^{-1}\right)$. The high absorption by OACs attenuated the light producing the shallowest $Z_{e u}$ registered at EPEA $\left(Z_{e u}=\right.$ $11.1 \mathrm{~m})$. Interestingly, in the following month (January 2009) stratification intensified reaching an extreme value of $d T d Z=-2.9$ and $Z_{d T d Z}=24.0$ $\mathrm{m}$, while $C h l_{T}$ decreased up to $0.353 \mathrm{mg} \mathrm{m}^{-3}$ and the ratio $\left[a_{P h y}(443) / a_{P h y}(676)\right]$ increased to 3.66 , a rather high value denoting a change in the phytoplankton composition. In turn, $a_{N A P}(443)$ and $a_{C D O M}(443)$ continued to be high $\left(0.06 \mathrm{~m}^{-1}\right.$ and $0.096 \mathrm{~m}^{-1}$, respectively), probably as a consequence of the bloom decay. Finally, in November 2016 another extreme increase in phytoplankton occurred, evidenced by both the high values of $C h l_{T}$ and $a_{P h y}(443)$ of $4.163 \mathrm{mg} \mathrm{m}^{-3}$ and $0.527 \mathrm{~m}^{-1}$ respectively. Possibly other extreme events have occurred at EPEA in between our onsite sampling.

\section{Trends in bio-optical and physical properties for the period 2000-2017}

$C h l_{T}$ and $C h l_{<5}$ showed significant increasing 

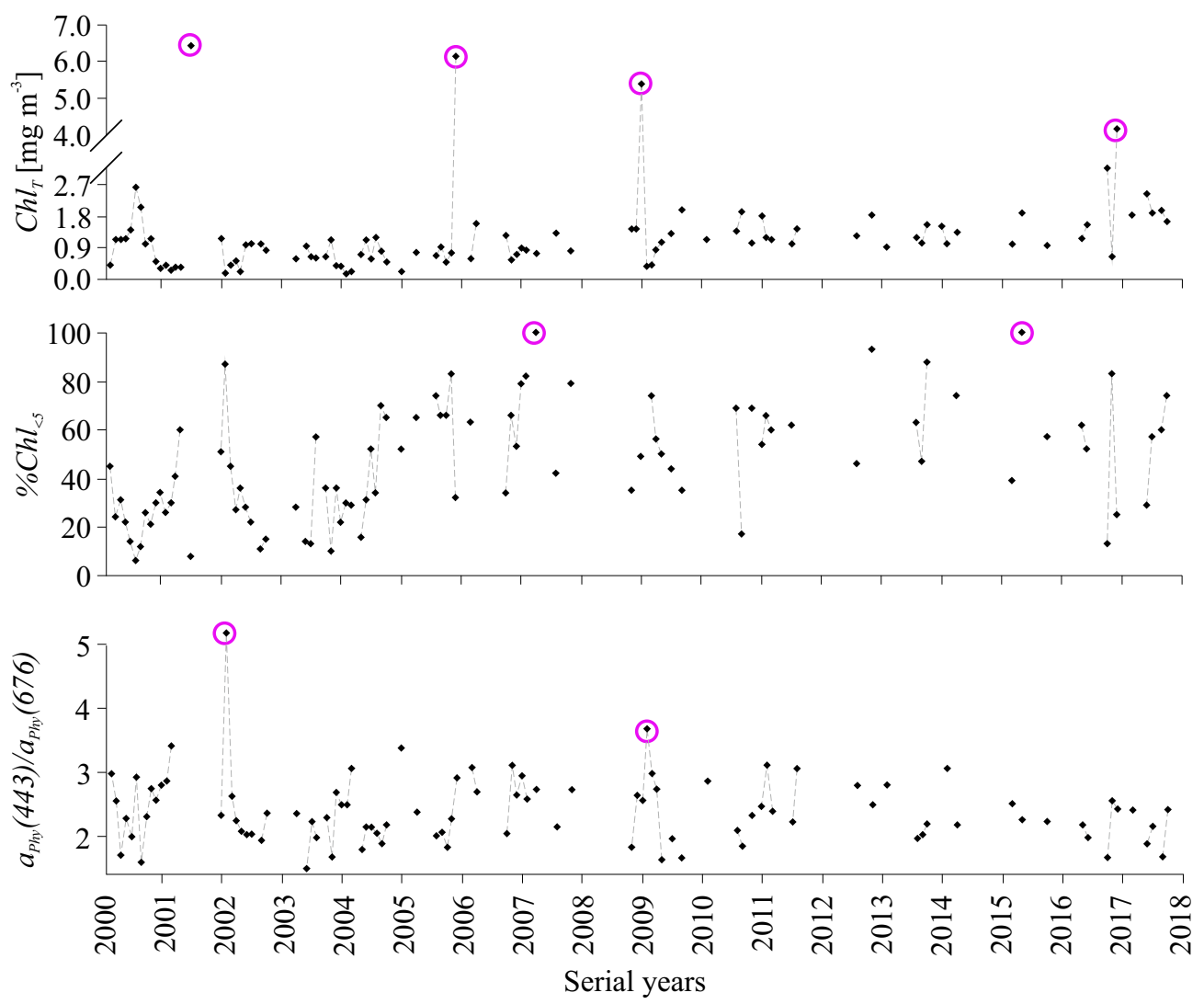

Figure 9. Inter-annual distribution of concentration of chlorophyll-a $C h l_{T}$, percentage of $C h l_{<5}$ from $C h l_{T}$, and ratio $\left[a_{P h y}(443) / a_{P h y}(676)\right]$ estimated for $5 \mathrm{~m}$ samples at EPEA for the period 2000-2017. Purple circles indicate extreme values ( $>2$ standard deviations).

trends (Table 3; Figures 11 and 12). Percentage of $C h l_{<5}$ also showed a significant positive trend (Figure 13), in agreement with the significant positive trend in the pico-phytoplankton fraction observed at EPEA (Silva, pers. comm.). On the other hand, the Seasonal Mann-Kendal test (SMK) revealed that the specific absorption coefficient of phytoplankton, $a^{B}{ }_{P h y}(443)$, decreased significantly during the same period (Figure 14). This trend appears to be simply governed by the increasing trend in chlorophyll, since an increase in pico-phytoplankton is expected to be reflected in an increase in the efficiency of light absorption per unit chlorophyll. The rest of properties studied didn't show any significant trend of change during the period analysed (Table 3 ).

\section{DISCUSSION}

Changes in the incident irradiance at EPEA seem to be the main driver of the seasonal formation of a warmer less dense upper layer separated by a thermocline from deep colder waters (Ruiz, 2018; Luz Clara, pers. comm.). Basic description of phytoplankton growth cycle in temperate seas explains that blooms occur in spring as the water column stratifies, allowing cells to remain in the lit zone at the same time that they have plenty of nutrients, which were replenished by mixing during the previous winter (Riley 1946). Nevertheless, at EPEA, except for special events, phyto- 

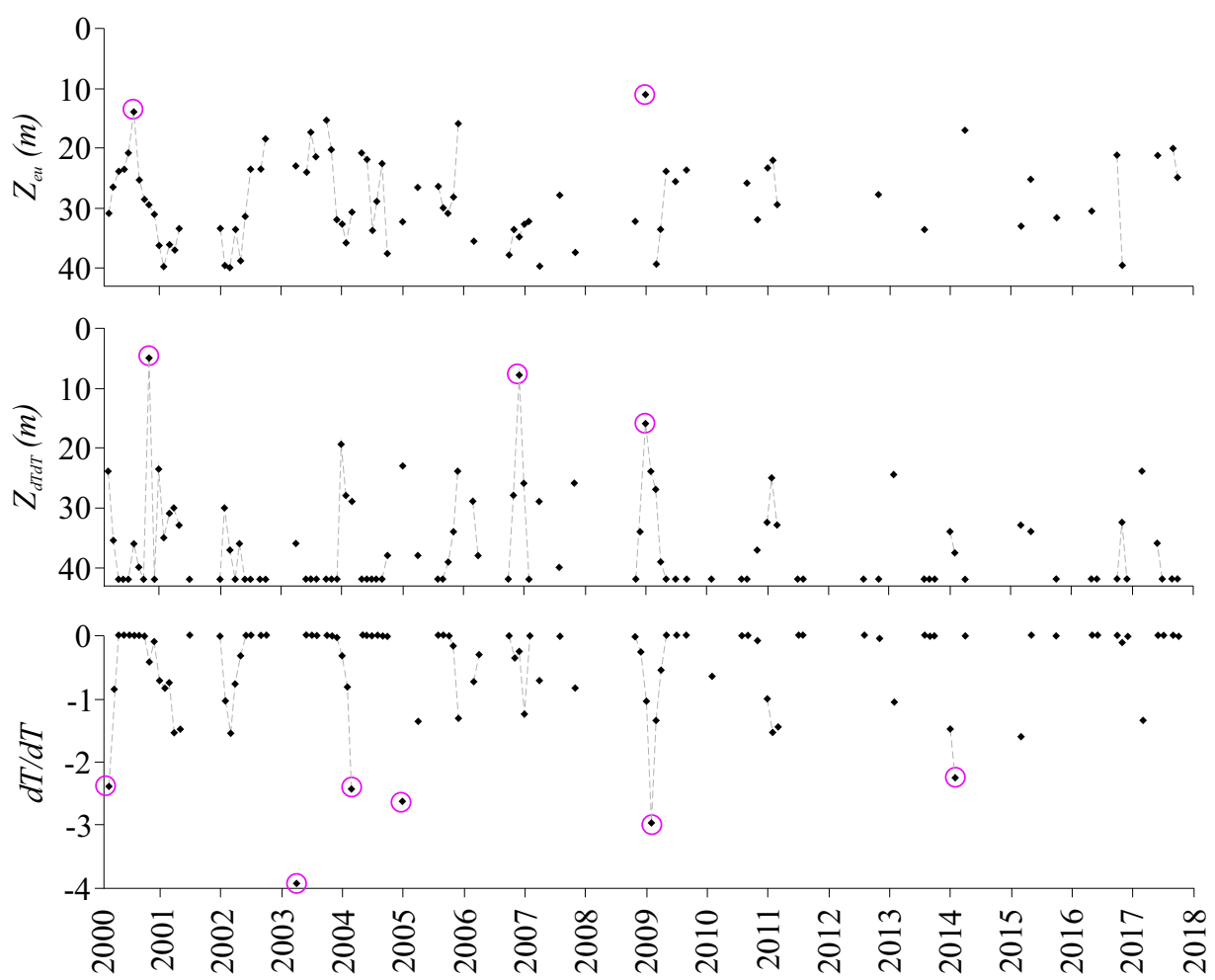

Serial years

Figure 10. Inter-annual distribution of euphotic depth, $Z_{e u}$, the depth at which the maximum value of the derivate of temperature with respect to depth (dT/dZ) occurred, $Z_{d T d Z}$, and the strength of the dT/dZ at EPEA for the period 2000-2017. Purple circles indicate extreme values ( $>2$ standard deviations).

Table 3. Values of $p$ obtained from the Seasonal Mann-Kendal test (SMK) trend analysis for bio-optical properties and thermal stratification parameters at EPEA for the period 2000-2017. Values marked in bold are significant at a $\alpha=0.05$ confidence level.

\begin{tabular}{lcc}
\hline Property & Trend sign & $p$ SMK \\
\hline$C h l_{T}$ & Positive & $\mathbf{0 . 0 0 0 1 3}$ \\
$C h l_{<5}$ & Positive & $<\mathbf{0 . 0 0 0 0 1}$ \\
$\% C h l_{<5}$ & Positive & $<\mathbf{0 . 0 0 0 0 2}$ \\
$a_{P h y}(443)$ & & 0.5945 \\
$a_{N A P}(443)$ & & 0.1878 \\
$a_{C D O M}(443)$ & & 0.2167 \\
$a_{P h y}^{B}(443)$ & Negative & $<\mathbf{0 . 0 0 0 0 3}$ \\
$a_{P h y}(443) / a_{P h y}(676)$ & & 0.5272 \\
$Z_{d T d Z}$ & & 0.2659 \\
$Z_{e u}$ & & 0.7282 \\
\hline
\end{tabular}




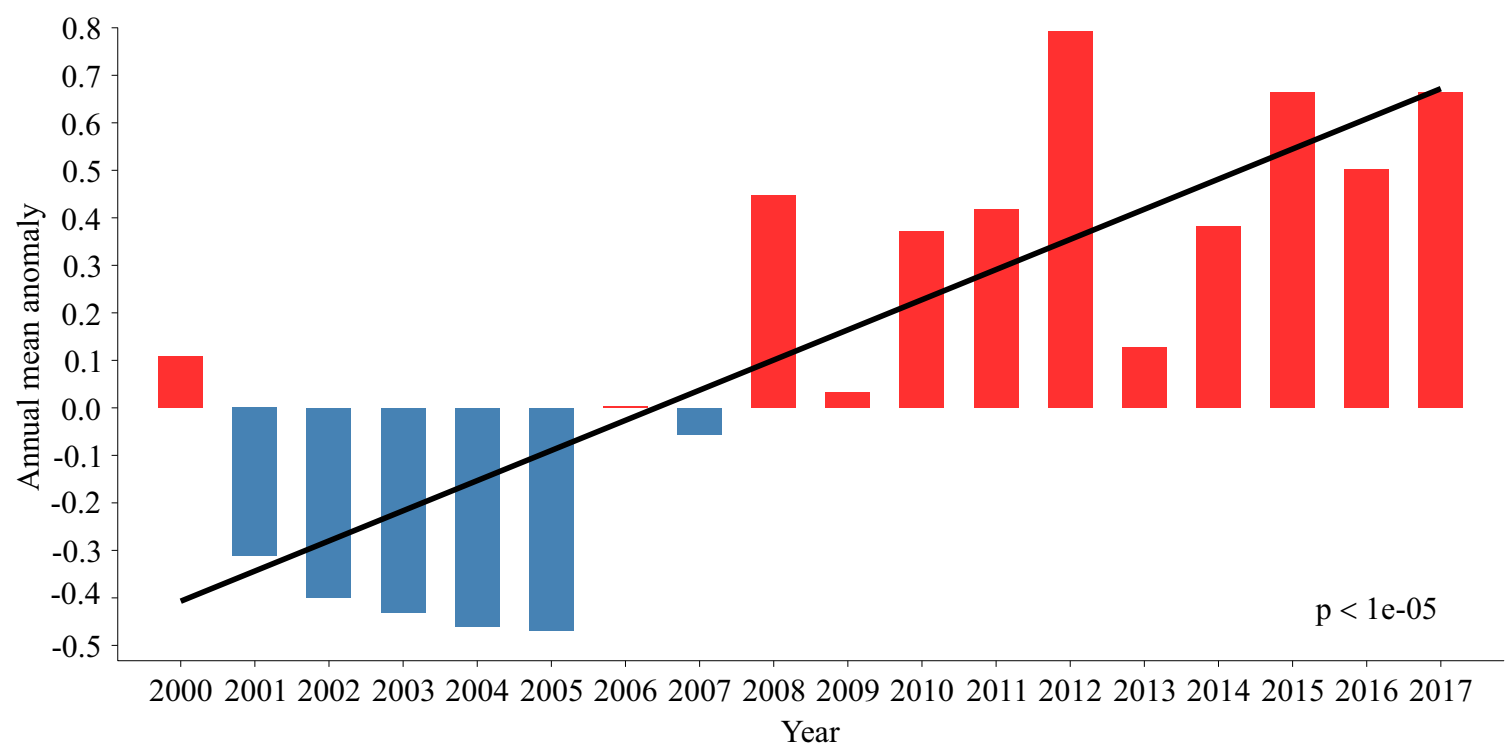

Figure 11. Annual mean $C h l_{T}$ anomalies for the period 2000-2017.

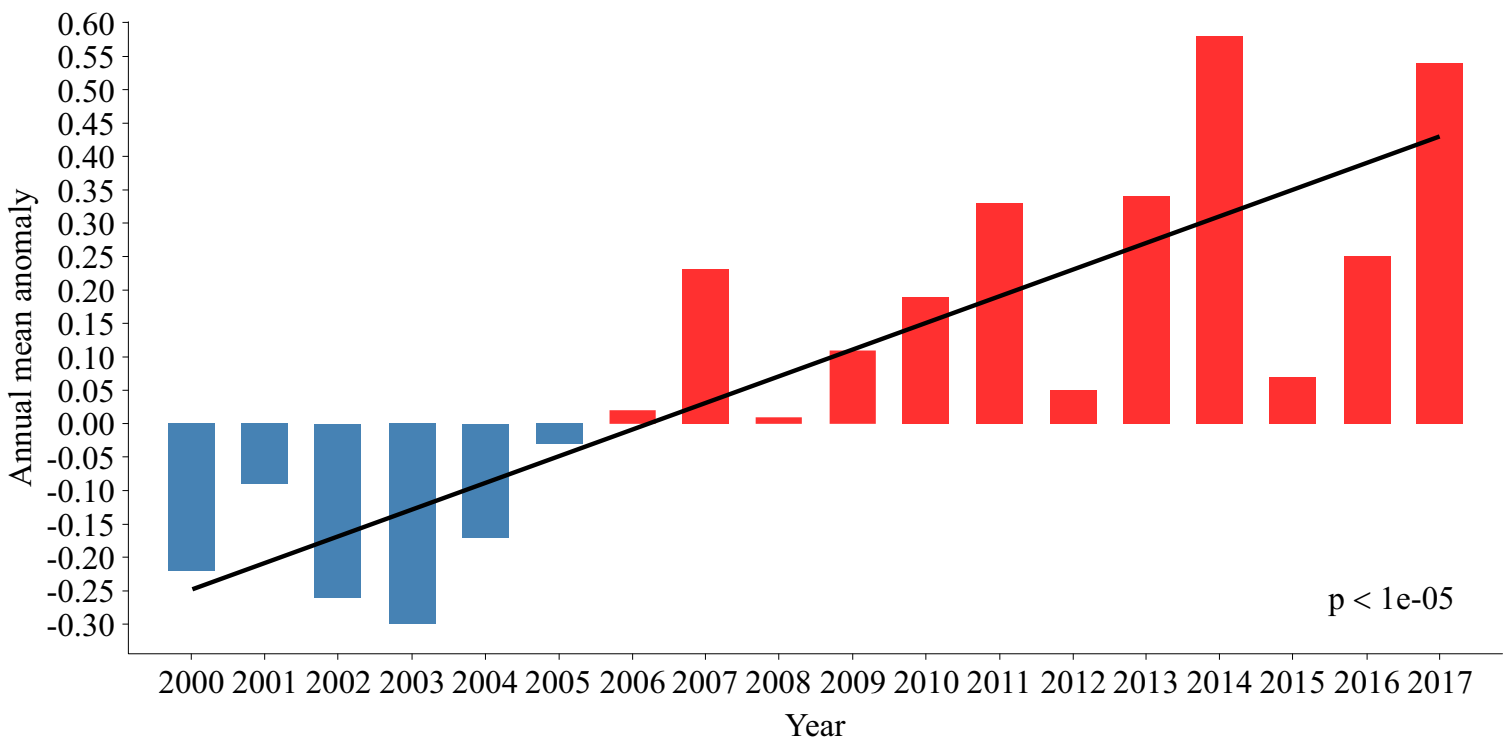

Figure 12. Annual mean $C h l_{<5}$ anomalies for the period 2000-2017.

plankton biomass as indicated by $C h l_{T}$ does not follow this dynamic, since $C h l_{T}$ tends to be higher at the end of winter. This could be due to the fact that bottom depth $(\sim 48 \mathrm{~m})$ is shallow enough to allow phytoplankton cells to be brought up by mixing to the lit layer with a frequency that per- mits them to grow, even during the darkest months at EPEA. Incident irradiance starts increasing in August, being the trigger for a relative increment in phytoplankton growth, whose biomass starts to decrease as the stratification progresses and nutrients are consumed (Negri et 


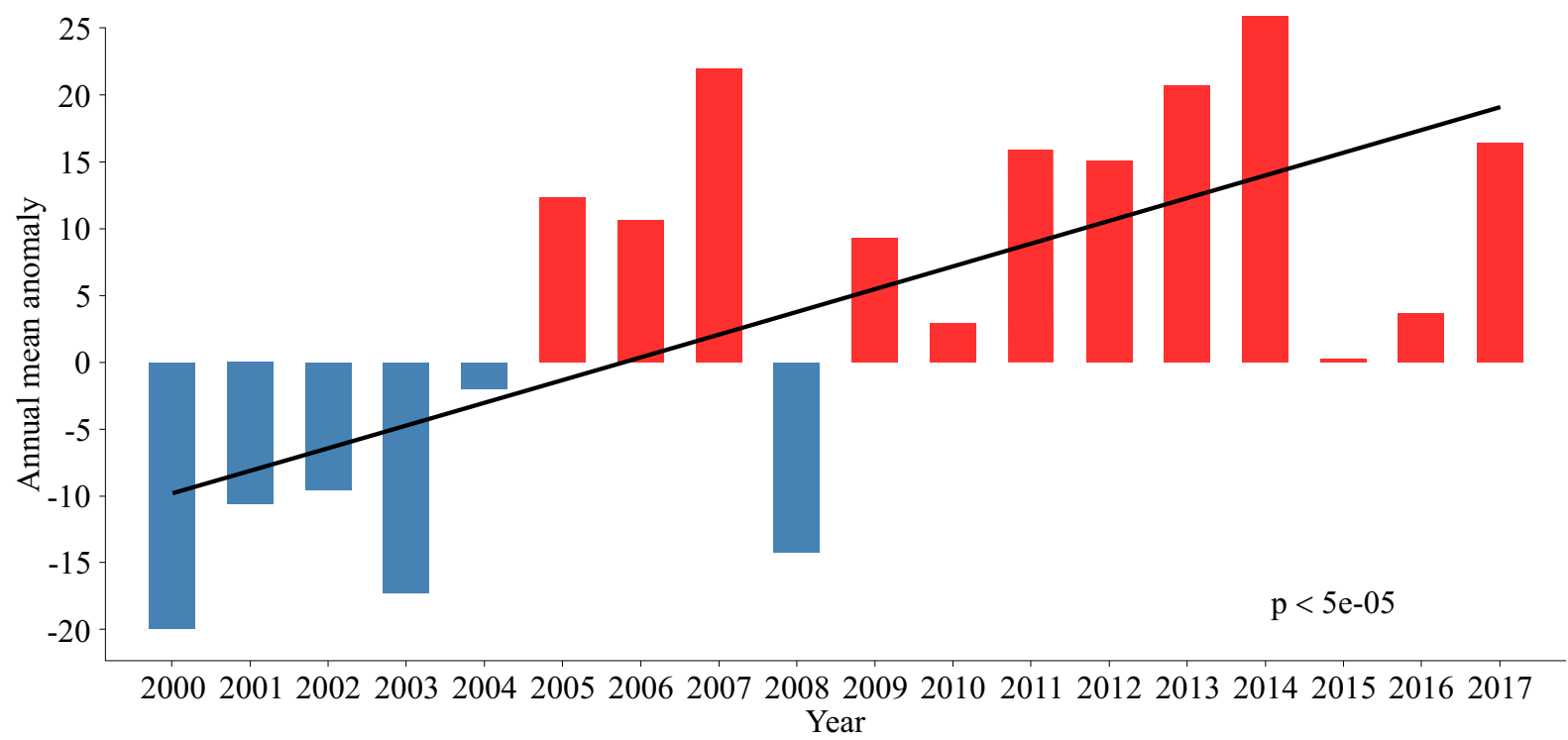

Figure 13. Annual mean $\% C h l_{<5}$ anomalies for the period 2000-2017.

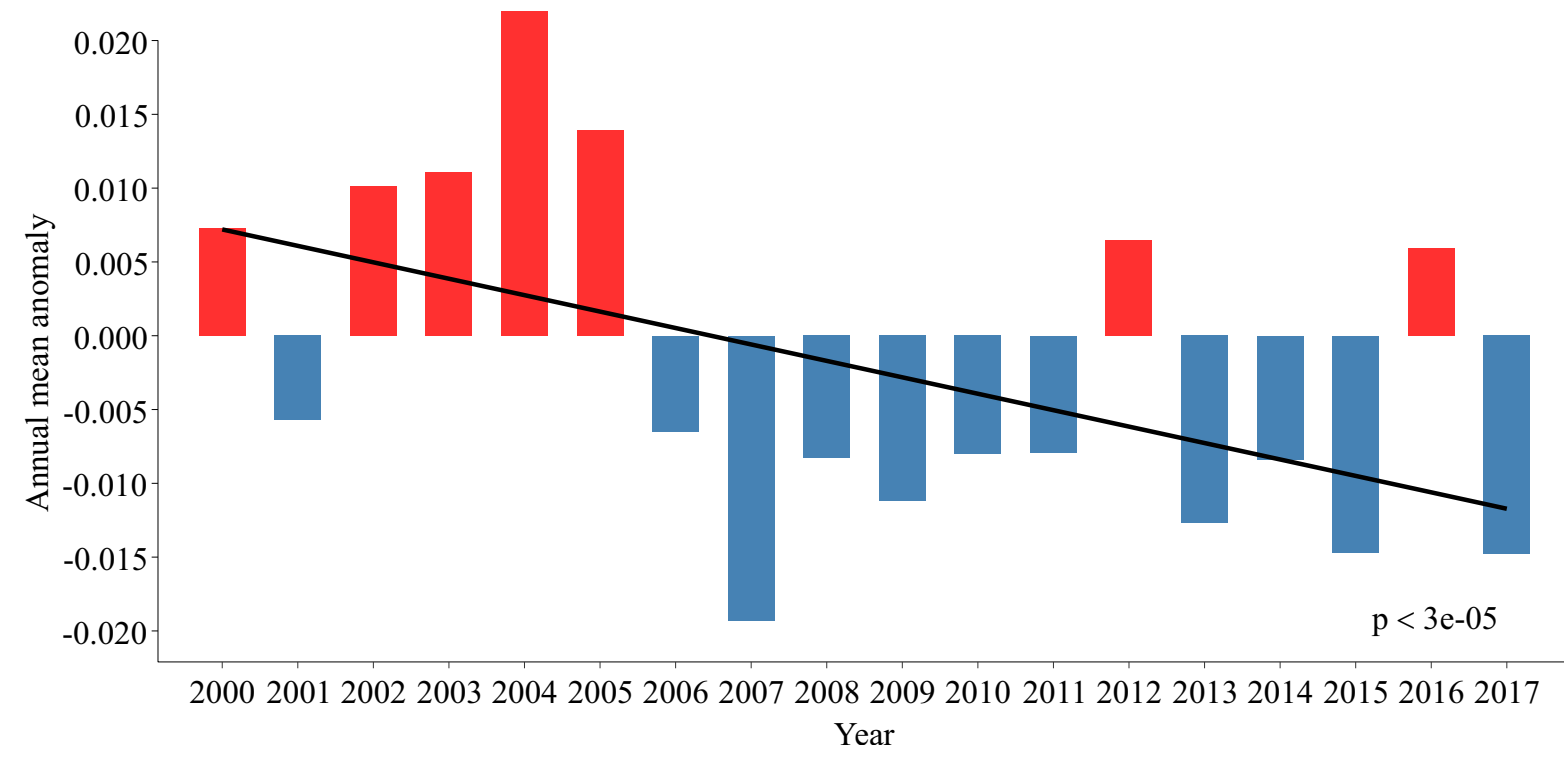

Figure 14. Annual mean $a^{B}{ }_{P h y}(443)$ anomalies for the period 2000-2017.

al. 2003; Carreto et al. 2004). Relationships among properties studied add evidence to this explanation since $C h l_{T}$ was significantly and positively correlated with $Z_{d T d Z}$ and significantly and negatively correlated with $Z_{e u}$.

It is known that small cells are more efficient to assimilate nutrients when these are scarce, due to their higher surface to volume ratio (Richardson et al. 1983; Chisholm 1992), and at the same time of being better suited to cope with high irradiances, which may cause photo-inhibition due to the higher proportion of photo-protective pig- 
ments, such as zeaxanthin in Synechococcus. Higher blue to red ratios have been attributed to the dominance of phytoplankton populations with small cell sizes and photoacclimated to high light (Sosik and Mitchell 1995; Millán-Núñez et al. 2004). At EPEA station, this photoacclimation strategy is evidenced in higher values of blue to red absorption ratio $\left[a_{P h y}(443) / a_{P h y}(676)\right]$ during summer and also in the correlation with the shallower and stronger stratification and deeper euphotic depth. A similar but not as conspicuous pattern was observed for $a^{B}{ }_{P h y}(443)$, a bio-optical property indicative of absorption efficiency which is usually negatively correlated with cell size. Thus, it is possible to discern the link of biooptical properties following main seasonal variations in phytoplankton types and how they photoacclimate, even at this optically complex coastal site.

Variations in the annual cycle of absorption coefficients of OACs at EPEA station for the period 2000-2017 have been previously analyzed (Lutz et al. 2006; Ruiz 2018). From those studies it became clear that $a_{C D O M}(443)$ is the OAC with largest values of absorption at all months (with peaks in fall and summer), followed by $a_{P h y}(443)$ (with almost no variation throughout the year), and finally $a_{N A P}(443)$ which is maximum in winter. The fact that at EPEA $a_{P h y}(443)$ did not show seasonal variability as it was in the case for $C h l_{T}$ could be due to the fact that the spectral absorption coefficient of phytoplankton is a complex bio-optical property that represents the sum of the absorption by different pigment-protein complexes present in different phytoplankton species that make up a given sample. However, $a_{P h y}(443)$ still was correlated to $C h l_{T}$, and it showed extreme values in events when phytoplankton biomass was high. As mentioned, the blue to red absorption ratio $\left[a_{P h y}(443) / a_{P h y}(676)\right]$ is a property that changes both with the phytoplankton community and with how the cells were photoacclimated, with the advantage that as being dimensionless it emphasizes these variations in the absorption spectral shape rather than in its magnitude (Sosik and Mitchell 1995). At EPEA, the annual cycle of $\left[a_{P h y}(443) / a_{P h y}(676)\right]$ showed higher values during the warm period; whether this suggests that phytoplankton populations are mainly composed of small cells (Negri and Silva 2003) or different size cells which were photoacclimated to high irradiances remains to be addressed.

Long term trends of change were observed both for $C h l_{T}, C h l_{<5}$ and $\% C h l_{<5}$. This fact could have been exacerbated by the change in the extraction method of the chlorophyll concentration determination that took place in 2006 at EPEA station (from acetone $90 \%$ to methanol $100 \%$ ), which is more efficient in the case of smaller cells (Lutz et al. 2010). Nevertheless, independent sources of $\mathrm{Chl}_{T}$ estimation (satellite) in the region also rendered an increasing trend (Marrari et al. 2017). However, despite the positive and significant correlation observed between $C h l_{T}$ and $a_{P h y}(443)$, long-term changes were not reflected in a significant trend of $a_{P h y}(443)$. This could have been possibly related to the wide seasonal variability of this coefficient and the fact that absorption coefficients are complex properties encompassing many factors. In agreement with the positive significant trend in $C h l_{<5}$, the picoplankton and nanoplankton size fractions showed significant positive trends (Silva, pers. Comm.). Contrary to what could be expected from these observations, we have observed a significant decreasing trend in the total $a_{P h y}^{B}(443)$ (which is a lineal combination of $C h l_{T}$, $\left.a_{P h y}^{B}(443)=a_{P h y}(443) / C h l_{T}\right)$ and no trend in $\left[a_{P h y}(443) / a_{P h y}(676)\right]$.

A few special bloom events were observed at EPEA, some of them associated with different extraordinary physical conditions. In 2001, an almost exclusively blooming of diatoms from the nano and micro planktonic size fraction was observed. In November 2005 a bloom of the Genus Prymnesium sp. was identified, characterized by the absence of micro planktonic diatoms. In December 2008, another maximum of phytoplankton occurred, which was associated with an 
event of cold temperature and characterized by the presence of atypical phytoplankton species for the study site and the absence of micro planktonic diatoms, which could be the reason why a relative high $a_{P h y}(443)$ was observed for the recorded $\mathrm{Chl}_{T}$ (Negri et al. 2015). The bloom observed in November 2016 was particular due to its high concentration of nano planktonic dinoflagellates. Whether the frequency of such events has been increasing at EPEA is a question that we cannot still assess upon our in situ database, mainly given the unfortunate gaps in the sampling. Nevertheless, in this work it has been shown that IOPs did capture these special events, indicating that satellite information should also be useful to detect them, even considering the possible inaccuracies of this data source for the study site (Ruiz 2018; IOCCG 2020). Long term time series of observations, either in situ or satellite, are not exempt from changes in the methodologies or from gaps in the sampling frequency. These two factors, together with the autocorrelation and decadal natural variability of oceanic ecosystems challenge the unambiguous detection of a trend, possibly driven by climate change, above the natural variability. It has been stated that time series of about 40 years long would be necessary to distinguish a trend from natural variability, assuming no gaps on the observational record (Henson et al. 2010). This is a condition that only very few ecological time series are able to meet so far, which points out the necessity of maintaining time series to assess changes occurring in the marine environment (O'Brien et al. 2017). Long-term in situ bio-optical data is particularly scarce in the global ocean. From the beginning of this time series to the present, the technological capacity implemented (ships, equipment, human resources) has been improved, and despite the irregular sampling frequency, this work based on the observations at EPEA emphasize the relevance of in situ ecological time series to contribute to the understanding of coastal ecosystems dynamics in a context of climate change.

\section{CONCLUSIONS}

Our results derived from almost two decades of in situ observations at this coastal site in the South Atlantic indicate an increasing trend in chlorophyll-a concentration, possibly due to an increase in the smaller fraction of phytoplankton. Although the absorption coefficient of phytoplankton did not follow a significant trend, it did represent the occurrence of special events of high biomass, which is an encouraging result for the use of satellite information at the study site. Two main parameters of phytoplankton absorption, the specific absorption coefficient of phytoplankton $a_{P h y}^{B}(443)$ and the blue to red ratio $\left[a_{P h y}(443) / a_{P h y}(676)\right]$, follow an annual cycle with high values in summer and low in winter, according to the probable dominance of different size cells and their expected acclimation to the light regime. Though, $a_{\text {Phy }}^{B}(443)$ showed a trend to decrease throughout the years, which is consistent with the increase in $\mathrm{Chl}_{T}$, but how this is connected to the increase in small cells should be further investigated. An in depth study of the variability in the phytoplankton absorption spectral shapes and its direct link to phytoplankton species and their photoacclimation status would be a next step at EPEA. Possible sources of CDOM should also be explored, since it is a major component absorbing light and was not correlated to any of the variables studied.

\section{ACKNOWLEDGEMENTS}

This work was supported by INIDEP and CONICET. The authors thank Daniel Cucchi Colleoni for his collaboration on board and laboratory analysis since the beginning of the time series. Special thanks to Daniel Hernández and Manuela Mendiolar who provided statistical 
advice, and to Ezequiel Cozzolino who provided satellite data. The authors are also thankful to the crew and captains of all the vessels used to achieve the sampling at EPEA time series and to the anonymous reviewers. INIDEP contribution no 2224.

\section{REFERENCES}

Auad G, Martos P. 2012. Climate vriability of the Northern Argentinean Shelf Circulation: impact on Engraulis Anchoita. Int J Ocean Clim Syst. 3 (1): 17-43.

Babin M, Stramski D, Ferrari GM, Claustre H, Bricaud A, Obolensky G, HoepFFner N. 2003. Variations in the light absorption coefficients of phytoplankton, nonalgal particles, and dissolved organic matter in coastal waters around Europe. J Geophys Res. 108 (C7, 3211). doi:10.1029/2001JC000882

BALdoni A. 2010. Clasificación temporal de los datos ocanográficos sobre la Plataforma Continental y Océano Atlántico Sudoccidental. Inf Invest INIDEP No 25/2010. 22 p.

Bricaud A, Babin M, Morel A, Claustre H. 1995. Variability in the chlorophyll-specific absorption coefficients of natural phytoplankton: Analysis and parameterization. J Geophys Res. 100 (NO. C7): 13321-13332.

Carreto Ji, Lutz VA, Carignan MO, Cucchi Colleoni AD, De Marco SG. 1995. Hydrography and chlorophyll a in a transect from the coast to the shelf-break in the Argentinian Sea. Cont Shelf Res. 15 (2/3): 315-336.

Carreto Ji, Montoya NG, Akselman R, Negri RM, Carignan Mo, Cucchi Colleoni AD. 2004. Differences in the PSP toxin profiles of Mytilus edulis during spring and autumn blooms of Alexandrium tamarense off Mar del Plata coast, Argentina. In: SteIdinger KA, LANDSberg JH, Tomas CR, VArgo GA, editors. Harmful Algae 2002. St. Petersburg,
Florida, USA: Florida Fish and Wildlife Conservation Commission, Florida Institute of Oceanography, and Intergovernmental Oceanographic Commission of UNESCO. p. 100-102.

Ciotti ÁM, Lewis MR, Cullen JJ. 2002. Assessment of the relationship between dominant cell size in natural phytoplankton communities and the spectral shape of the absorption coefficient. Limnol Oceanogr. 47 (2): 404417.

Chisholm SW. 1992. Phytoplankton size. In: WoOdHEAD PGFAAD, editor. Primary productivity and biogeochemical cycles in the sea. New York and London: Plenum Press. p 213-237.

DAVIES L, GATHER U. 1993. The identification of multiple outliers. J Am Stat Assoc. 88 (423): 782-792.

Delgado AL, Guinder VA, Dogliotti AI, ZAPPeri G, Pratolongo PD. 2019. Validation of MODIS-Aqua bio-optical algorithms for phytoplankton absorption coefficient measurement in optically complex waters of El Rincón (Argentina). Cont Shelf Res. 173: 73-86.

Ducklow HW, Doney SC, Steinberg DK. 2009. Contributions of long-term research and timeseries observations to marine ecology and biogeochemistry. Annu Rev Mar Sci. 1 (1): 279302.

DutKiewicz S, Hickman AE, Jahn O, Henson S, Beaulieu C, Monier E. 2019. Ocean colour signature of climate change. Nature Communications. 10 (1): 578. doi:10.1038/s41467019-08457-x

DuYENS LNM. 1956. The flattering of the absorption spectrum of suspensions, as compared to that of solutions. Biochim Biophys Acta. 19: 1-12.

Ferreira A, Ciotti AM, Mendes CRB, Uitz J, BRICAUD A. 2009. Phytoplankton light absorption and the package effect in relation to photosynthetic and photoprotective pigments in the northern tip of Antarctic Peninsula. J Geo- 
phys Res (C Oceans). 122 (9): 7344-7363.

Henson SA, Sarmiento JL, Dunne JP, Bopp L, Lima I, Doney SC, John J, Beaulieu C. 2010. Detection of anthropogenic climate change in satellite records of ocean chlorophyll and productivity. Biogeosciences. 7 (2): 621-640.

Hernández DR, Mendiolar M. 2018. Manual del Programa CSMK. Implementación de un Test no paramétrico para datos estacionales con dependencia serial y datos faltantes. Inf. Ases y Transf INIDEP No 143/2018. 13 p.

HiRSCH RM, Slack JR. 1984. A Nonparametric Trend test for seasonal data with serial dependence. Water Resour Res. 20 (6): 727-732.

HoEPFFNER N, SATHYENDRANATH S. 1992. Biooptical characteristics of coastal waters: absorption spectra of phytoplankton and pigment distribution in the western North Atlantic. Limnol Oceanogr. 37 (8): 16601679.

Holm-Hansen O, LoRenzen CJ, Holmes RW, STRICKLAND DH. 1965. Fluorometric determination of chlorophyll. Journal du Conseil. 30 (1): 3-15.

[IOCCG] InTERnATIONAL OCEAN-COLOUR COORDINATING GROUP. 2020. Synergy between ocean colour and biogeochemical/ecosystem models. In: DutKIEWICZ S, editor. Report of the International Ocean-Colour Coordinating Group (IOCCG). Dartmouth, NS, Canada. N ${ }^{\circ}$ 19. 184 p. doi:10.25607/OBP-711

[IPCC] Intergovernmental Panel on Climate CHANGe. 2019. Summary for policymakers. In: Pörtner H-O, Roberts DC, MASSONDelmotte V, Zhai P, Tignor M, PoloczansKa E, Mintenbeck K, Alegría A, Nicolai M, OKEM A, et al., editors. IPCC Special Report on the Ocean and Cryosphere in a Changing Climate. https://www.ipcc.ch/srocc/chapter/ summary-for-policymakers/.

Johnsen G, SAKShaug E. 1996. Light harvesting in bloom-forming marine phytoplankton: species-specificity and photoacclimation. Sci Mar. 60 (1): 47-56.
Kishino M, TAKahashi M, OKami N, ICHIMURA S. 1985. Estimation of the spectral absorption coefficients of phytoplankton in the sea. Bull Mar Sci. 37 (2): 634-642.

LONGHURST A. 1995. Seasonal cycles of pelagic production and consumption. Prog Oceanogr. 36: 77-167.

Lutz VA, Sathyendranath S, Head EJH, Li WKW. 2001. Changes in the in vivo absorption and fluorescence excitation spectra with growth irradiance in three species of phytoplankton. J Plankton Res. 23 (6): 555-569.

Lutz VA, Sathyendranath S, Head EJH, Li WKW. 2003. Variability in pigment composition and optical characteristics of phytoplankton in the Labrador Sea and the Central North Atlantic. Mar Ecol Prog Ser. 260: 1-18.

Lutz VA, Segura V, Dogliotti AI, Gagliardini DA, Bianchi A, Balestrini CE. 2010. Primary Production in the Argentine Sea during spring estimated by field and satellite models. J Plankton Res. 32 (2): 181-195.

Lutz VA, Subramaniam A, Negri RM, Silva RI, CARreto JI. 2006. Annual variations in biooptical properties at the 'Estación Permanente de Estudios Ambientales (EPEA)' coastal station, Argentina. Cont Shelf Res. 26 (10): 1093-1112.

Marrari M, Piola AR, Valla D. 2017. Variability and 20-Year Trends in Satellite-Derived Surface Chlorophyll Concentrations in Large Marine Ecosystems around South and Western Central America. Front Mar Sci. 4 (372).

Millán-NúÑEZ E, Sieracki ME, MilláN-NúÑEZ R, LARA-LARA JR, GaXiola-CAstro G, Trees CC. 2004. Specific absorption coefficient and phytoplankton biomass in the southern region of the California current. Deep-Sea Res II. 51: 817-826.

Mitchell BG. 1990. Algorithms for determining the absorption coefficient of aquatic particulates using the quantitative filter technique (QFT). Ocean Optics X. Orlando, FL, United States: SPIE. p. 137-148. 
Negri RM, Carreto Ji, Lutz VA, Carignan MO, Cucchi Colleoni AD. 2003. Condiciones ambientales en la estación EPEA ( $38^{\circ} 28^{\prime}$ S-57 $41^{\prime} \mathrm{W}$ ) durante un ciclo anual. V Jornadas Nacionales de Ciencias del Mar. Mar del Plata, Argentina. 146.

Negri RM, Lutz VA, Silva Ri, Carignan MO, Ruiz MG, Hozbor C, Molinari GN, Montoya NG, Segura V, Berghoff CF, et al. 2015. Eventos especiales en magnitud y génesis en la serie de tiempo ambiental y de plancton "EPEA" en el Mar Argentino. In: CAMPos N, Ospino M, Arellano E, Garay C, Rodríguez L, editors. XVI Congreso Latinoamericano de Ciencias del Mar - Colacmar y XVI Seminario Nacional de Ciencias y Tecnologías del Mar. Santa Marta, Colombia: Entrelibros e-book solutions. 575 p.

Negri RM, Silva RI. 2003. Contribución de las distintas fracciones del fitoplancton a la biomasa fototrófica durante un ciclo anual en la estación EPEA ( $\left.38^{\circ} 28^{\prime} \mathrm{S}-57^{\circ} 41^{\prime} \mathrm{W}\right)$. V Jornadas Nacionales de Ciencias del Mar. Mar del Plata, Argentina. 147.

Negri R, SiLva RI. 2011. Estructura de la comunidad del fitoplancton en la estación costera EPEA durante el período 2000-2010 (provincia de Buenos Aires, Argentina). Bol Soc Argent Bot. 46 (Supl): 99-100.

O'BRIEN T, RE, LORENZONI L, ISENSEE K, VALDES L, editors. 2017. What are Marine Edcological Time Series telling us about the ocean? A status report. IOC-UNESCO. IOC Technical Series. $N^{\circ} 129.297$ p.

PrieUr L, SATHYENDARANATH S. 1981. An optical classification of coastal and oceanic waters based on the specific spectral absorption curves of phytoplankton pigments, dissolved organic matter, and other particulate materials. Limnol Oceanogr. 26 (4): 671-689.
Richardson K, Beardall J, Raven JA. 1983. Adaptation of unicellular algae to irradiance: an analysis of strategies. New Phytol. 93: 157191.

RILEY GA. 1946. Factors controlling phytoplankton populations on Georges bank. J Mar Res. 6: 54-73.

RuIz MG. 2018. Variabilidad de las propiedades bio-ópticas en la serie de tiempo Estación Permanente de Estudios Ambientales (EPEA) complementando mediciones in situ y satelitales [PhD thesis]. Mar del Plata: Universidad Nacional de Mar del Plata. 137 p.

Ruiz MG, Lutz VA, Frouin R. 2017. Spectral absorption by marine chromophoric dissolved organic matter: laboratory determination and piecewise regression modeling. Mar Chem. 194: 10-21.

Sathyendranath S, Lazzara L, Prieur L. 1987. Variations in the spectral values of specific absorption of phytoplankton. Limnol Oceanogr. 32 (2): 403-415.

Segura V, Lutz VA, Dogliotti A, Silva RI, Negri RM, Akselman R, Benavides H. 2013. Phytoplankton types and primary production in the Argentine Sea. Mar Ecol Prog Ser. 491: 15-31.

Silva RI, Negri RM, Lutz VA. 2009. Summer succession of ultraphytoplankton at the EPEA coastal station (Northern Argentina). J Plankton Res. 31 (4): 447-458.

SosiK HM, Mitchell BG. 1995. Light absorption by phytopIankton, photosynthetic pigments and detritus in the CaIifornia current System. Deep-Sea Res. 42 (10): 1717-1748.

Williams GN, Larouche P, Dogliotti AI, LATORRE MP. 2018. Light absorption by phytoplankton, non-algal particles, and dissolved organic matter in San Jorge Gulf in summer. Oceanography. 31 (4): 40-49. 
